\title{
Service Quality Dimensions of Electricity Services: Evidence from Electricity Board in Sri Lanka
}

\author{
S. Achchuthan ${ }^{1}$, N. Sivathaasan ${ }^{2} \&$ J. M. R. S. Jayasundara ${ }^{1}$ \\ ${ }^{1}$ Faculty of Management Studies, Sabaragamuwa University of Sri Lanka \\ ${ }^{2}$ Library, University of Jaffna, Sri Lanka \\ Correspondence: S. Achchuthan, Department of Marketing Management, Faculty of Management Studies, \\ Sabaragamuwa University of Sri Lanka, PO box 02, Belihuloy, 70140, Sri Lanka. Tel: 94-77-836-4899. E-mail: \\ achchu2009@gmail.com
}

Received: June 19, 2013 Accepted: July 16, 2014 Online Published: August 20, 2014

doi:10.5539/ass.v10n17p194

URL: http://dx.doi.org/10.5539/ass.v10n17p194

\begin{abstract}
The paper tries to develop an empirical model of service quality in terms of electricity services that may form a basis for a better understanding of its determinants. Specifically, it's aimed to identify the dimensions of service quality of electricity services provided by the Ceylon Electricity Board located in Badulla District. The study employs exploratory factor analysis (EFA) and the service quality dimensions are identified using it as an independence technique. Data were collected by a structured questionnaire that consists of two sections as Part A and $\mathrm{B}$. A total of 300 usable responses $(n=300)$ were obtained through simple random sampling technique. The model consists of five dimensions such as tangibility, empathy, responsiveness, reliability, and assurance that have been detected by exploratory factor analysis. Further, results revealed that dimensions extracted from the analysis accounted for 62.899 percent of the total variance. While the study limits to the electricity services provided by the public sector organization based in Badulla district, the findings introduce the dimensions of service quality for electricity services, which may be a base for other scholars.
\end{abstract}

Keywords: service quality, exploratory factor analysis, Sri Lanka

\section{Background of the Study}

Today, public sector organizations have to face many challenges in hyper competitive environment. Further, public sector should focus on service quality and also frame strategic aspects with help of the concept as service quality (Sotirakou \& Zeppou, 2005; Wright \& Pandey, 2010). Due to the above mentioned reasons, public sector organizations in developed and developing countries have to modernize their functions and work more efficiently (Pal \& Ireland, 2009; Torres et al., 2005).

Due to the current management scenario, both internal and external sources stressed the public sector organizations to focus on their functions and to modernize it successfully (Hughes \& Smart, 2012). Further, public sector needs to demonstrate that, they have the capacity to improve their performance and achieve organizational goals and objectives. Therefore, the development and the application of effective performance management approaches seem imperative (Parka \& Raineyb, 2012). Meanwhile, strategic issues should be applied among public sector organizations to compete with private sector. In this context, Uhr (1990) suggested the public sector to adopt the private sector service system, which is named as "managerialism". Furthermore, researchers argued that, managerialism is considered as the strategic formula to make successful one among public sector.

In Sri Lankan Context, the Ceylon Electricity Board is a government sector organization. Especially, in the South Asian Region, Sri Lanka has been ranked the best one in terms of electrification rate (Central Bank Report, 2013). Meanwhile, as a whole, public sector organizations have been stressed to deliver quality services and improve efficiencies (Randall \& Senior, 1994; Robinson, 2003). In addition, Since Sri Lanka has gained independence in 1948, the public sector has undergone a number of transformations. The public sector is under increasing pressure to demonstrate that their services are customer-focused and that continuous performance improvement is being delivered. Importantly, In the Asian region, china and India have already achieved 8 percentage of growth level. Output gap between advanced and emerging economies has been narrowing over the 
past decade and is expected to narrow even further going forward. Meanwhile, Sri Lankan economy has achieved 5 percentage of growth level approximately for recent four decades (Sri Lankan Economic Outlook, 2012; Velnampy \& Achchuthan, 2013). Especially, in Sri Lanka, Badulla region is considered as an emerging one, particularly in the industrial and agricultural development (Central Bank Report, 2013). The purpose of this research is thus to examine the service quality concepts and their application in the Ceylon Electricity Board in Badulla area. The study uses the SERVQUAL approach to examine the gap between customers' general expectations of a service and their perceptions of the services of specific service provider. This research investigates how closely customer expectations of service and employees perceptions of customer expectations are matched. This approach has been used extensively to assess the quality of public sector services.

Generally, electricity power supply for domestic and industrial sector took a vital role in economic development. In nutshell, electricity services are recognized as the live blood to the nation and its development. Further, it provides the power or energy to other industries to do the functions properly and perfectly. If there is a problem in terms of power supply, whole economy will be in question mark. Due to that, government should focalize electricity services as prominent and fundamental one. Furthermore, in the third world countries, many cases of violations of the rights, such as incorrect calculation of bills (increasing penalties, calculation on power capability, etc.), an unreasonable restriction of power supply, are not adequately addressed by the electricity consumers (Balakrishnan, Kanet, \& Sridharan, 1999). In this context, public in the Badulla region had 13018 complaints against Ceylon Electricity Board regarding to the service quality as they provide their services, which have been extracted from the Record Book in complain-2014, Ceylon electricity board, Badulla. Table 1 shows the complaints lodged regarding the service quality for the last few years.

Table 1. Consumer complaints

\begin{tabular}{lc}
\hline Year & No of Complaints \\
\hline 2010 & 9786 \\
2011 & 10322 \\
2012 & 12087 \\
2013 & 12314 \\
2014 & 13018 \\
\hline
\end{tabular}

Source: Summary of Consumer Complains- 2014

Therefore, this study is an effort to come up with the solution to the major research problem that can be titled, as "An Assessment of Service Quality in Ceylon Electricity Board- (With special reference to Badulla area). Due to that, the current study desires to develop an empirical model of service quality in terms of electricity services that may form a basis for a better understanding of its determinants. Specifically, this study aims to identify the dimensions of service quality of electricity services provided by the Ceylon Electricity Board located in the Badulla District.

\section{Service Quality in the Public Sector: Concepts and Measurements}

In the globalized level, the service industry is viewed as the back bone of the economy and it has prominent place in the economic structure to support to the agriculture and industrial sector. In hyper competitive environment, delivering quality service is considered as an essential strategy for the success and survival (Parasuraman, Zeithmal \& Berry, 1985; Reichheld \& Sasser, 1990). Further, Personalized and close relationship with service providers are recognized as better aspects to enhance the customer satisfaction and loyalty, which will lead to customer retention concept beyond the short-term financial goal to the long-term relational value. The relational value paradigm (between: customer and employee; customer and service organization; employee and service organization; service provider and service intermediaries) has now become more important than ever before. In this context, service quality practices in public sector organizations are slow and are further exacerbated by difficulties in measuring outcomes, greater scrutiny from the public and press, a lack of freedom to act in an arbitrary fashion and a requirement for decisions to be based in law (Teiche, 2002; Ramseook-Munhurrun, 2012).

The concept "services" is approached differently by scholars, in that view point, Gronroos (2000) pointed that, services are normally intangible in nature, but not necessarily, it takes place at the time of interaction between the customer and service employees or the service provider, which are provided as solutions to clients' problems. Interestingly, Edvardsson (2005) mentioned that, services as processes that are produced and consumed with the involvement of customers. Elaborately, Brochado (2009) discussed the distinctive characteristics as intangibility, inseparability, heterogeneity and perishability to differentiate the services from the product. Further, in the same 
way, the concept of service quality is also viewed differently by the scholars in the marketing paradigm. Zeithaml (2000) focalized the service quality as the critical component of customer perceptions about the service. Further, Customers perceive services in terms of its quality and how satisfied they are overall with their experiences. In this way, Czepiel (1990) approached the service quality as customers' perception of how well a service meets or exceeds their expectations. In a supportive way, Gronroos (2007) stated that, perceived service quality as a consumption process in which the customer is part of the service process that leads to an outcome or result. Further, according to Parasuraman et al., (1988) service quality is the customer's judgment of overall excellence of the service or the difference between customer's expectations (Kang \& James, 2004). In addition, in the various sources, the term "quality" is interpreted and used systematically. In this way, quality is denoted as the level of well-being, which indicates the response of a person to physical, mental and social changes in life. Furthermore, Vitkiene (2004) mentioned that, quality is the human ability to create wide, informative, overall, creative attitude to many things, as quality is based on social, ethical, cultural, historical experience, generally acceptable and individual perception.

Importantly, service quality is widely accepted concept in the world of marketing. Further, as a broadly accepted concept, service quality has the wide range of measurements, which have been discussed by various research findings in the developed and developing countries (Ushantha, Wijeratne, \& Achchuthan, 2013). In this context, two main aspects have been utilized and followed by the researchers in the concept of service quality; one is viewed as difference between the expectations and perception of the service. This was framed by Parasuraman et al., (1988) who view service quality as a comparison between customer's expectations and perception of service quality. Second approached is viewed as an attitude based. Cronin and Taylor (1992) approached the service quality as the consumer attitude towards services. Meanwhile, SERVQUAL model which was originally developed by Parasuraman et al., $(1985,1988)$ can be utilized to the research approaches on the public sector service quality assessment also with the slight modification. In a supportive way, SERVQUAL model has been used as the research model for measuring service quality in the marketing paradigm especially both in developed and developing countries (Robinson, 1999). Further, still now, the model is recognized as a perfect model to give the insights to the marketing strategy.

Providing better level of public services is generally considered as complex process, in which, finding out unexpressed needs, setting priorities, allocating resources and publicly justifying and accounting for what has been done are not easy to fulfill systematically (Gowan, Segmour \& Ibarrenche, 2001). Further, Public sector services, which take the prominent place in the day to day life and also those, are responsible and accountable to citizens and communities as well as to its customers. Researches on service quality in public sectors have been focused by several scholars (Wisniewski, 2001; Brysland \& Curry, 2001).

Studies on service quality in the electricity has not been studied and approached fruitfully in the both developed and developing countries. Meanwhile, this effort should be considered as a pioneer step in the marketing paradigm, which approaches the service quality in the electricity services. Further, Sri Lanka is recognized as an emerging country in terms of industrial development and also economic growth has been increasing trend since 2010. Due to that, power supply in terms of electricity is the fundamental and denoted as the backbone to the economy and its development. Therefore, this research surely gives fruitful suggestions to the policy makers and researchers regarding to the service quality in electricity services. In addition, in the consumers' view, electricity service is believed as the main aspect to measure the standard of living.

\section{Research Methodology}

According to Uma and Roger (2012), the population is the entire group of people, events, or things that the researcher desires to investigate. In this study, all the consumers who consume the electricity power in Badulla district are taken as the target population. They are approximately 115015, according to Department of Census and Statistics. A sample of 383 users out of total population was selected according to the table for determining sample size from a given population (Krejcie \& Morgan, 1970) at $95 \%$ of confidence level. The rules of thumb proposed by Roscoe (1975) suggest that sample size larger than 30 and less than 500 are appropriate for most research. Hence, the sample size determined for this research is consistent with the above criteria. The data were collected during the month of April 2014. The researchers being the residents of place personally distributed the questionnaire using simple random sampling technique to the users and confirmed their willingness to respond the same. As a result, a total of three hundred and eighty three questionnaires (383) were given to the respondents and three hundred were retrieved (300) with the response rate of 78 percent, which is sufficient for the survey. 
Survey method performs as a significant way of gathering information (Fei, 2006). A research design should be well designed, in a way to facilitate the collection of relevant evidence and information for the research, efficiently (Kothari, 1990; Sivathaasan, Murugathas, \& Chandrasekar, 2014). In this study, survey method is a questionnaire, which has a set of questions to which the respondents record their answers. This was developed based on previous review of literature. The questionnaire consists of two sections as part A \& part B. In Part A, questions related to demographic profile such as gender, age, marital status, occupations, and income were asked from the respondents. Then, variables are grouped into categories and measured on nominal scale by assigning code numbers to the objects. Likewise, in Part B, service quality of electricity services on twenty two statements or items were tested. All items are measured on interval scale and respondents are requested to indicate their degree of agreement or disagreement on a 7-point scale, ranging from strongly disagree (1) to strongly agree (7).

A pilot study of 30 respondents was conducted before the actual survey and this assisted to make necessary corrections in the questionnaire. The primary and secondary data were collected for the purpose of carrying out the research. Primary data refer to the information that was developed or gathered by the researchers specifically for the research project at hand (Burns et al., 2006). In this study, primary data were collected through a self-administered questionnaire and secondary data were collected from books, journals, and magazines, research reports etc. The data collected was then analyzed by using a Statistical Package for Social Science (version 20).

Various statistical methods were employed to analyze the data such as descriptive and inferential analyses. The descriptive statistics have been used to display the sample profile of the respondents. Further, reliability test, test of sampling adequacy and factor analysis were performed to identify the critical factors, which determine service quality dimensions of electricity services. Specially, the factor analysis technique has been used to extract relevant dimensions from the 22 statements on service-quality.

\section{Results and Discussion}

\subsection{Participants}

The sample consists of 56 percent male (168) and 44 percent female (132) respondents. Among those, 37 percent are self-employed, while 24 and 21 percent are working in government and private sectors. The majority of the respondents (i.e. 37.3 per cent) belong to the age group of 18- 28 years, followed by the age group of 29-38 and $39-48$ that constitute 25.3 percent of total respondents.

Further, Most of the respondents belong to the middle class income group with monthly income ranging from LKR 21,000 - 30,000. 32 percent male are receiving high salary, which is above LKR 30,000. Around 57 percent female respondents are earning middle class income, compared to male respondents. The summary of personal variables which include gender, age, marital status, nature of work and salary range is recorded in table 2 .

Table 2. Summary of personal variables

\begin{tabular}{|c|c|c|c|}
\hline \multicolumn{2}{|c|}{ Description of Personal Variables } & No of consumers & Percentage \\
\hline \multirow[t]{2}{*}{ Gender } & Male & 132 & $44 \%$ \\
\hline & Female & 168 & $56 \%$ \\
\hline \multirow[t]{4}{*}{ Age } & Between 18 and 28 years & 101 & $33.7 \%$ \\
\hline & Between 29 and 38 years & 76 & $25.3 \%$ \\
\hline & Between 39 and 48 years & 76 & $25.3 \%$ \\
\hline & Above 48 years & 47 & $15.7 \%$ \\
\hline \multirow[t]{2}{*}{ Marital Status } & Married & 139 & $46.3 \%$ \\
\hline & Single & 161 & $53.7 \%$ \\
\hline \multirow{4}{*}{ Nature of work } & Government Employees & 72 & $24 \%$ \\
\hline & Private sector employees & 62 & $20.7 \%$ \\
\hline & Self-employees & 111 & $37 \%$ \\
\hline & Unemployment & 55 & $18 \%$ \\
\hline \multirow[t]{3}{*}{ Salary } & Below LKR 20, 000 & 93 & $31 \%$ \\
\hline & Between LKR 20,001 - 30,000 & 134 & $44.7 \%$ \\
\hline & Above LKR 30, 000 & 73 & $24.3 \%$ \\
\hline
\end{tabular}

Source: Survey Data, 2014

\subsection{Test of Reliability and Validity}

According to Black (1999), reliability is an indication of consistency between two measures of the same dimension. The reliability of the factors needs to be determined in order to support to any measures of validity that may be employed (Nunnally, 1978). 
To measure the reliability of each factor derived from factor analysis, internal consistency analysis was employed. This internal reliability is generally verified by Cronbach's alpha, indicating range between 0 and 1 . An alpha of 0.6 or higher will be considered adequate in exploratory research (Black \& Porter, 1996). But, the widely recognized rule of thumb for internal reliability is 0.7 (Nunnally, 1978). Table 3 shows the reliability coefficient calculated for each factor.

Table 3. Statistics of Reliability Coefficient

\begin{tabular}{llc}
\hline Code & \multicolumn{1}{c}{ Statement } & Alpha Value \\
\hline TAN1 & The electricity board has modern-looking equipment. & .845 \\
TAN2 & The electricity board's physical facilities are visually appealing. & .843 \\
TAN3 & The electricity board's employees are neat appearing. & .842 \\
TAN4 & Materials associated with the service (such as forms, electricity bill etc.) visually & .845 \\
REL1 & Electricity board services are performed within the promised time. & .844 \\
REL2 & When I have a problem, the electricity board's employees show sincere interest in & .845 \\
REL3 & The electricity board correctly performs the service right the very first time. & .870 \\
REL4 & The electricity board provides its service right the first time. & .846 \\
REL5 & The electricity board insists on error free records.(calculate electricity bill) & .849 \\
RES1 & In the electricity board I do not spent much time waiting in line. & .850 \\
RES2 & Electricity board employees are always willing to help. & .850 \\
RES3 & Electricity board employees are quick in eliminating potential errors. & .846 \\
RES4 & Electricity board employees quickly respond to my requests. & .845 \\
ASS1 & Electricity board employees are trustworthy. & .847 \\
ASS2 & I feel safe in using electricity power. & .849 \\
ASS3 & Electricity board employees consistently courteous towards me. & .849 \\
ASS4 & Electricity board employees have the knowledgeable to answer my questions. \\
EM1 & The electricity board provides me an individual attention. & .849 \\
EM2 & The electricity board has convenience operating hours to my needs. & .849 \\
EM3 & The electricity board has employees who give me personal attention. & .847 \\
EM4 & The electricity board considers my wishes and needs. & .848 \\
EM5 & Electricity board employees show understanding of my specific needs. & .849 \\
\hline
\end{tabular}

Instruments are generally considered reliable when they have an alpha of 0.80 or higher on a scale of 0 to 1 (Rubin \& Babbie, 2009). As can be seen in the above table, alpha values range from 0.842 to 0.870 , indicating that calculated alphas are above threshold. Hence, scales developed suggest good internal consistency.

Table 4. Guidelines for KMO test

\begin{tabular}{cc}
\hline KMO Value & Degree of Common Variance \\
\hline 0.90 to 1.00 & Marvelous \\
0.80 to 0.89 & Meritorious \\
0.70 to 0.79 & Middling \\
0.60 to 0.69 & Mediocre \\
0.50 to 0.59 & Miserable \\
0.00 to 0.49 & Don't Factor or unacceptable \\
\hline
\end{tabular}

Bartlett's Test of Sphericity and the Kaiser-Meyer-Olkin Test of Sampling Adequacy (KMO) are commonly used to provide more complex measures for assessing the strength of the relationships and suggesting factorability of the variables (Beavers, Lounsbury, Richards, Huck, Skolits, \& Esquivel, 2013). Kaiser (1974) recommends that the accepted index of KMO \& Bartlett's Test of Sphericity should be over 0.5. Also, the Bartlett's Test of Sphericity relates to the significance of the study and thereby shows the validity and suitability of the responses collected to the problem being addressed through the study. 
The guidelines to interpret the Kaiser-Meyer-Olkin measure (Nimalathasan, 2009; Beavers et al., 2013; Sivathaasan \& Chandrasekar, 2013) are presented in table 4.

In the current study, value for KMO matrix is 0.797 , which falls under the range of middling and test value of chi-square is 2928.941 , which is significant at five percent level $(\mathrm{p}<0.05)$. Hence, data indicate the suitability and appropriateness. Table 5 summarizes the statistics derived from the analysis in relation to KMO measure and Bartlett's Test.

Table 5. KMO measure and Bartlett's test

\begin{tabular}{lcc}
\hline \multicolumn{2}{c}{ Description } & Value \\
\hline Kaiser-Meyer-Olkin Measure of Sampling Adequacy & 0.797 \\
Bartlett's Test of Sphericity & Approx. Chi-Square & 2928.941 \\
& df (degree of freedom) & 231 \\
& Significant & .000 \\
\hline
\end{tabular}

\subsection{Exploratory Factor Analysis (EFA)}

Factor analysis is a general name denoting a class of procedures primarily used for data reduction and summarization (Malhotra, \& Satyabhushan, 2010).The study employs the exploratory factor analysis (EFA) to identify the underlying dimensions or factors of service quality of Ceylon Electricity Board with Principal Component Analysis (PCA) extraction method. According to Malhotra, \& Satyabhushan (2010), PCA is an approach to factor analysis that considers the total variance in the data.

For extraction of the factors, the following three criteria(s) were used:

a) Eigen values greater than or equal to 1 were used to identify the number of factors. The eigenvalue is a value associated with each factor describing the amount of variance in the items that can be explained by that factor (Pett, Lackey, \& Sullivan, 2003).

b) Items with a loading smaller than 0.5 (low factor loadings) on any factor were deleted. For parsimony, only factors with loadings above 0.5 were considered significant (Pal, 1986; Pal \& Bagi, 1987).

c) Items that demonstrated cross-loadings greater than 0.5 on more than one factor were dropped, assuming that no pure measures of a specific construct are provided (Olorunniwo, Hsu, \& Udo, 2006).

According to the criteria, an EFA was first performed on all 22 variables using principal component extraction method. For analytical purpose, each statement on the questionnaire was assigned numbers (refer to the table 3).Through the examination of factor loadings, item ASS4 was removed after the first run of factor analysis and six factors were extracted. Then, the remaining 21 items were analyzed by PCA with Varimax rotation to determine the critical variables and factors through the second run of factor analysis. A scree plot was constructed for the remaining items and it shows the discontinuity of the variable "ASS 4" (see figure 1). Hence, the first factors extracted by the procedure were appropriate for the second run of factor analysis.

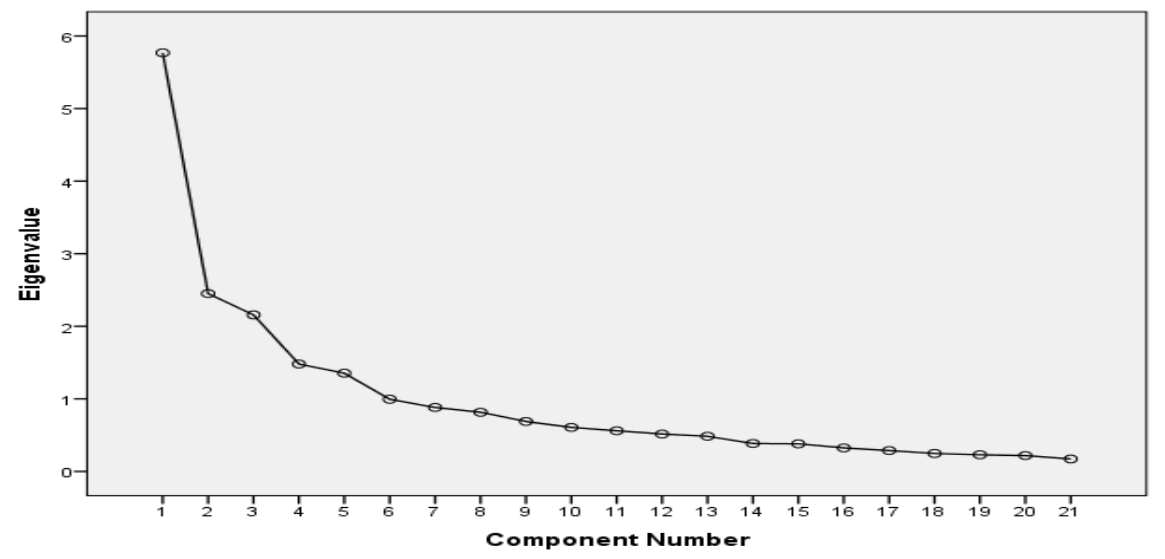

Figure 1. Scree plot

The highest and the lowest loadings for this analysis were 0.843 and 0.533 respectively. The procedure resulted in a five factor solution rotated by Varimax rotation. These five factors extracted together account for 62.899 
percent of the total variance. On examining content of the items, factors are labeled as tangibility, empathy, responsiveness, reliability, and assurance. This is shown in table 6 .

Table 6. Factor loadings structure matrix

\begin{tabular}{cclc}
\hline Factor & Factor (variance) & \multicolumn{1}{c}{ Variables included in the factors } & Factor \\
\hline F1 & Tangibility & The electricity board has modern-looking equipment. & .843 \\
& \multirow{2}{*}{ (16.464) } & The electricity board's physical facilities are visually appealing. & .841 \\
& & The electricity board's employees are neat appearing. & .809 \\
& & Materials associated with the service (such as forms, electricity bill etc.) & .743 \\
& & Electricity board services are performed within the promised time. & .606 \\
\hline F2 & Empathy & The electricity board provides me an individual attention. & .573 \\
& \multirow{2}{*}{$(13.932)$} & The electricity board has convenience operating hours to my needs. & .720 \\
& & The electricity board has employees who give me personal attention. & .793 \\
& & The electricity board considers my wishes and needs. & .713 \\
& & Electricity board employees show understanding of my specific needs. & .794 \\
\hline F3 & Responsiveness & In the electricity board I do not spent much time waiting in line. & .842 \\
& \multirow{2}{*}{ (13.790) } & Electricity board employees are always willing to help. & .784 \\
& & Electricity board employees are quick in eliminating potential errors. & .829 \\
& & Electricity board employees quickly respond to my requests. & .697 \\
\hline F4 & Reliability & When I have a problem, the electricity board's employees show sincere & .569 \\
& \multirow{2}{*}{ (9.843) } & The electricity board correctly performs the service right the very first & .533 \\
& & The electricity board provides its service right the first time. & .790 \\
& & The electricity board insists on error free records.(calculate electricity & .668 \\
\hline F5 & Assurance & Electricity board employees are trustworthy. & .597 \\
& (8.869) & I feel safe in using electricity power. & .788 \\
& & Electricity board employees consistently courteous towards me. & .695 \\
\hline
\end{tabular}

Factor 1 that was labelled as tangibility was composed of five items and accounted for 16.464 per cent of the variance. The items in this dimension were similar to the original dimension and a new item was added. Factor 2 comprised of five items related to the empathy and 13.932 per cent of the variance was explained. Factor 3 that included four items was labelled as responsiveness. Likewise, factor 4 named as reliability and factor 5 named as assurance explained the variance by 9.843 and 8.869 per cent respectively. The one item coded as "ASS4" was removed during the $1^{\text {st }}$ run of EFA. As a result, a model that determines service quality dimensions relating to electricity services is proposed with the above five factors. This model shown in figure 2 was derived from statistical evidence.

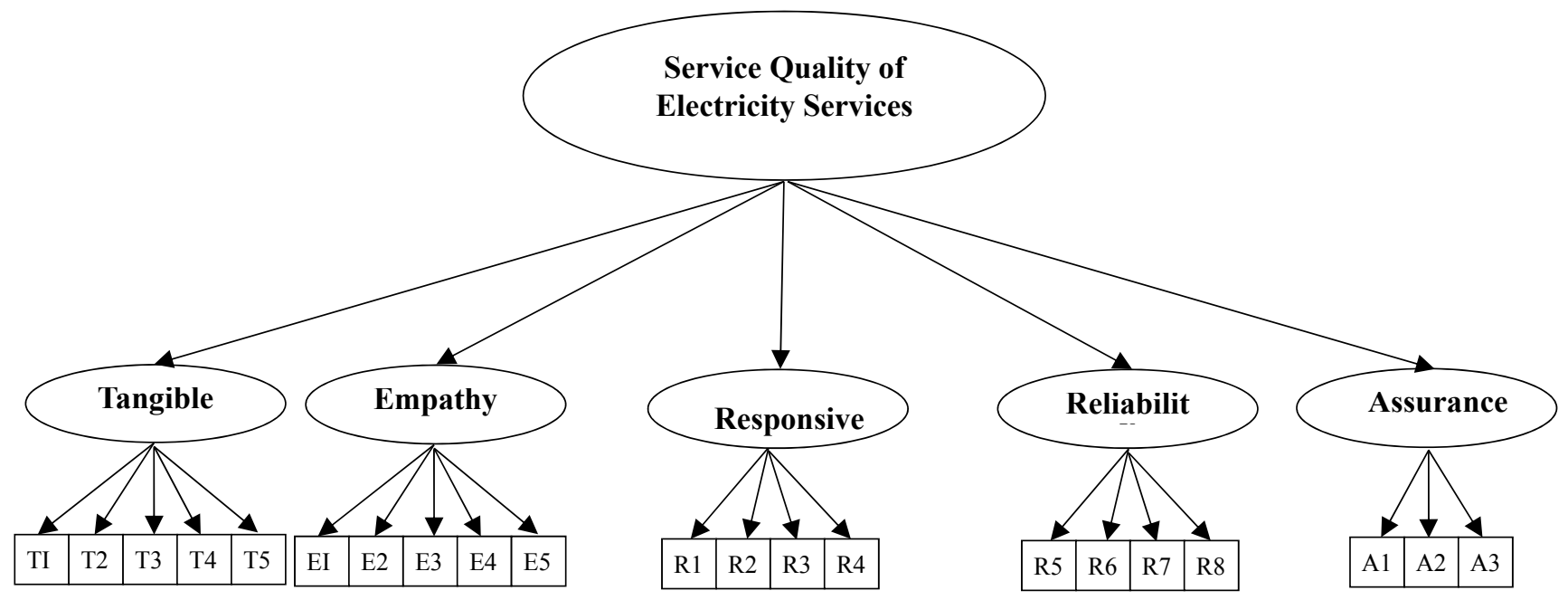

Figure 2 . Service quality model 


\section{Conclusion}

The research presents the results of a study carried out on dimensions of service quality model for electricity services provided by the Ceylon Electricity Board in Sri Lanka. A total of 22 statements or items were considered in the questionnaire. To construct the questionnaire, the SERVQUAL model proposed by Parasuraman et al., (1988), was used as the main guide. Exploratory factor analysis was employed to identify the dimensions of the service quality and after the $2^{\text {nd }}$ run of factor analysis; five factors or dimensions were identified with $21 \mathrm{key}$ variables. Those five dimensions were classified as the first order factors of service quality dimensions of electricity services in Sri Lankan context. These measure tangibility, empathy, responsiveness, reliability, and assurance. Moreover, factors extracted from the analysis accounted for $62.899 \%$ of the total variability. The list of statements categorized under each dimension is annexed herewith as appendix 1. Further, the present study concentrates only on electricity services provided by the public sector organization based in Badulla district. In future, scholars may be interested to confirm either the identified dimensions of service quality or to polish-up the dimensions in the electricity services.

\section{References}

Balakrishnan, N., Kanet, J. J., \& Sridharan, V. (1999). Early/tardy scheduling with sequence dependent setups on uniform parallel machines. Computers and Operations Research, 26(2), 127-141. http://dx.doi.org/10.1016/ S0305-0548(98)00051-3.

Beavers, A. S., Lounsbury, J. W., Richards, J. K., Huck, S. W., Skolits, G. J., \& Esquivel, S. L. (2013). Practical considerations for using exploratory factor analysis in educational research. Practical Assessment, Research \& Evaluation, 18(6), 2. Retrieved from http://www.pareonline.net/pdf/v18n6.pdf

Black, S. A., \& Porter, L. J. (1996). Identification of the Critical Factors of TQM. Decision Sciences, 27(1), 1-21. http://dx.doi.org/10.1111/j.1540-5915.1996.tb00841.x.

Black, T. R. (1999). Doing quantitative research in the social sciences: An integrated approach to research design, measurement and statistics. Sage.

Brochado, A. (2009). Comparing alternative instruments to measure service quality in higher education. Quality Assurance in education, 17(2), 174-190.

Brysland, A., \& Curry, A. (2001). Service improvements in public services using SERVQUAL. Managing service quality, 11(6), 389-401. http://dx.doi.org/10.1108/09604520110410601.

Cronin Jr, J. J., \& Taylor, S. A. (1992). Measuring service quality: A reexamination and extension. The journal of marketing, 55-68.

Czepiel, J. A. (1990). Service encounters and service relationships: implications for research. Journal of Business Research, 20(1), 13-21. http://dx.doi.org/10.1016/0148-2963(90)90038-F.

Edvardsson, B. (2005). Service quality: Beyond cognitive assessment. Managing Service Quality, 15(2), 127-131. http://dx.doi.org/10.1108/09604520510585316.

Gowan, M., Seymour, J., Ibarreche, S., \& Lackey, C. (2001). Service quality in a public agency: Same expectations but different perceptions by employees, managers, and customers. Journal of Quality Management, 6(2), 275-291. http://dx.doi.org/10.1016/S1084-8568(01)00040-2.

Grönroos, C. (2007). Service management and marketing: customer management in service competition. John Wiley \& Sons.

Hughes, P., Smart, J., Robinson, C., McGinnis, M. V., Aziz, O., Gibbons, M., \& Hawke, G. (2012). 'You say you want a revolution'... the next stage of public sector reform in New Zealand. Policy Quarterly, 8(1), 3-8. Retrieved from http://igps.victoria.ac.nz/publications/files/07507439782.pdf

Kaiser, H. F. (1974). An index of factorial simplicity. Psychometrika, 39(1), 31-36.

Kang, G. D., \& James, J. (2004). Service quality dimensions: An examination of Grönroos's service quality model. Managing Service Quality, 14(4), 266-277. http://dx.doi.org/10.1108/09604520410546806.

Krejcie, R., \& Morgan, D. (1970). Determining sample size for research activities. Educational and Psychological Measurement, 30, 607-610.

Malhotra, N. K., \& Satyabhushan, D. (2010). Marketing Research: An Applied Orientation. 6/E. Pearson Education India.

Nimalathasan, B. (2009). Determinants of key performance indicators (KPIs) of private sector banks in Sri 
Lanka: an application of exploratory factor analysis. The USV Annals of Economics and Public Administration, 9(2), 9-17

Nunnally, J. C. (1978). Psychometric theory (2nd ed.). New York: McGraw-Hill.

Olorunniwo, F., Hsu, M. K., \& Udo, G. J. (2006). Service quality, customer satisfaction, and behavioral intentions in the service factory. Journal of Services Marketing, 20(1), 59-72.

Pal, L. A., \& Ireland, D. (2009). The public sector reform movement: Mapping the global policy network. Intl Journal of Public Administration, 32(8), 621-657. http://dx.doi.org/10.1080/01900690903000187

Pal, Y., \& Bagai, O. P. (1978). A common factory bettery reliability approach to determine the number of interpretable factors. Paper presented at the IX Annual Conference of the Indian Society, India.

Pal, Y. A. (1986). A theoretical study of some factor analysis problems. Paper presented at the IX Annual Conference of the Indian Society, India.

Parasuraman, A., Zeithaml, V. A., \& Berry, L. L. (1985). A conceptual model of service quality and its implications for future research. The Journal of Marketing, 41-50. Retrieved from http://faculty.mu.edu.sa/public/uploads/1360593395.8791service\%20marketing70.pdf.

Parasuraman, A., Zeithaml, V. A., \& Berry, L. L. (1988). Servqual. Journal of retailing, 64(1), 12-40.

Park, S. M., \& Rainey, H. G. (2012). Work motivation and social communication among public managers. The International Journal of Human Resource Management, 23(13), 2630-2660. http://dx.doi.org/10.1080/ 09585192.2011.637060.

Pett, M. A., Lackey, N. R., \& Sullivan, J. J. (2003). Making sense of factor analysis: The use of factor analysis for instrument development in health care research. Sage.

Ramseook-Munhurrun, P. (2012). Perceived service quality in restaurant services: Evidence from Mauritius. International Journal of Management and Marketing Research, 5(3), 1-14. Retrieved from http://www.theibfr.com/ARCHIVE/IJMMR-V5N3-2012.pdf\#page=3

Randall, L., \& Senior, M. (1994).A model for achieving quality in hospital hotel services. International Journal of contemporary hospitality management, 6(1/2), 68-74. http://dx.doi.org/10.1108/09596119410052161

Reichheld, F. F., \& Sasser Jr, W. E. (1989). Zero defections: Quality comes to services. Harvard business review, 68(5), 105-111. Retrieved from http://europepmc.org/abstract/MED/10107082

Roscoe, J. T. (1969). Fundamental research statistics for the behavioral sciences (p. 239). New York: Holt, Rinehart and Winston.

Rubin, A., \& Babbie, E. (2009). Research methods for social work (7th ed.). Pacific Grove, CA: Brooks Cole.

Sivathaasan, N., \& Chandrasekar, K. (2013). Factor analysis of user satisfaction: a special reference to the library, University of Jaffna, Sri Lanka. Merit Research Journal of Art, Social Science and Humanities, 1(3), 40-46. Retrieved from http://www.meritresearchjournals.org/assh/index.htm.

Sivathaasan, N., Murugathas, K., \& Chandrasekar, K. (2014). Attitude towards the usage of electronic information resources in Medical Library, University of Jaffna, Sri Lanka. Information and Knowledge Management, 4(1), 86-93.

Sotirakou, T., \& Zeppou, M. (2005). How to align Greek civil service with European Union public sector management policies: A demanding role for HR managers in the contemporary public administration context. International Journal of Public Sector Management, 18(1), 54-82. http://dx.doi.org/10.1108/ 09513550510576152

Teich, T. (2002). Extended value chain management: EinKonzeptzurKoordination von Wertschöpfungsnetzen. (Doctoral dissertation, Chemnitz, Techn. Univ., Habil.-Schr., 2003). Retrieved from http://nbn-resolving.de/ urn:nbn:de:swb:ch1-200401108

Torres, L., Pina, V., \& Royo, S. (2005). E-government and the transformation of public administrations in EU countries: Beyond NPM or just a second wave of reforms?. Online Information Review, 29(5), 531-553.

Uhr, J. (1990). Ethics and the Australian public service: Making managerialism work. Current Affairs Bulletin, $66(11), 22-27$.

Uma, S., \& Roger, B. (2012). Research methods for business: A skill building approach. John Wiley \& Sons Ltd.

Ushantha, R. C., Wijeratne, A. W., \& Achchuthan, S. (2014). An Assessment of Retail Service Quality: An 
Empirical Study of the RSQS in Sri Lankan Supermarkets. Developing Country Studies, 4(3), 78-90.

Velnampy, T., \& Achchuthan, S. (2013). Fiscal deficit and economic growth: A study on Sri Lankan economic perspective. Developing Country Studies, 3(3).

Vitkienė, E. (2004). Recreation and Tourism business labour market while integration in the European Union. Scientific Journal: BRIDGES: Humanities \& Social Sciences, 4(29), 55-62.

Wisniewski, M. (2001). Using SERVQUAL to assess customer satisfaction with public sector services. Managing Service Quality, 11(6), 380-388. http://dx.doi.org/0.1108/EUM0000000006279.

Wright, B. E., \& Pandey, S. K. (2009). Transformational leadership in the public sector: Does structure matter?. Journal of public administration research and theory, mup003. Retrieved from http://jpart.oxfordjo urnals.org/content/early/2009/04/30/jopart.mup003.full.

Yu, F. (2006). Users' emotional and material satisfaction at the micro/macro levels in an academic library (Doctoral dissertation). University of Pittsburgh.

\section{Appendix}

Appendix A: List of 21 statements in the service quality model of electricity services

Tangibility

T1 The electricity board has modern-looking equipment.

T2 The electricity board's physical facilities are visually appealing.

T3 The electricity board's employees are neat appearing.

T4 Materials associated with the service (such as forms, electricity bill etc.) visually appealing at the

T5 Electricity board services are performed within the promised time.

Empathy

E1 The electricity board provides me an individual attention.

E2 The electricity board has convenience operating hours to my needs.

E3 The electricity board has employees who give me personal attention.

E4 The electricity board considers my wishes and needs.

E5 Electricity board employees show understanding of my specific needs.

\section{Responsiveness}

R1 In the electricity board I do not spent much time waiting in line.

R2 Electricity board employees are always willing to help.

R3 Electricity board employees are quick in eliminating potential errors.

R4 Electricity board employees quickly respond to my requests.

\section{Reliability}

R5 When I have a problem, the electricity board's employees show sincere interest in solving the problem.

R6 The electricity board correctly performs the service right the very first time.

R7 The electricity board provides its service right the first time.

R8 The electricity board insists on error free records.(calculate electricity bill)

\section{Assurance}

A1 Electricity board employees are trustworthy.

A2 I feel safe in using electricity power.

A3 Electricity board employees consistently courteous towards me.

\section{Copyrights}

Copyright for this article is retained by the author(s), with first publication rights granted to the journal.

This is an open-access article distributed under the terms and conditions of the Creative Commons Attribution license (http://creativecommons.org/licenses/by/3.0/). 